\title{
CREM wt Allele
}

National Cancer Institute

\section{Source}

National Cancer Institute. CREM wt Allele. NCI Thesaurus. Code C162404.

Human CREM wild-type allele is located in the vicinity of 10p11.21 and is approximately 86 $\mathrm{kb}$ in length. This allele, which encodes cAMP-responsive element modulator protein, is involved in the modulation of gene transcription. A fusion involving this gene and the FUS gene may be associated with epithelial tumors. 